\title{
Correction to: Sinus augmentation analysis of the gradient of graft consolidation: a split-mouth histomorphometric study
}

\author{
Roni Kolerman $^{1}$ (D) $\cdot$ Joseph Nissan ${ }^{2} \cdot$ Marina Rahmanov $^{2} \cdot$ José Luis Calvo-Guirado $^{3} \cdot$ Nirit Tagger Green $^{1} \cdot$ Haim Tal $^{1}$
}

Published online: 11 April 2019

(C) Springer-Verlag GmbH Germany, part of Springer Nature 2019

\section{Correction to: Clinical Oral Investigations https://doi.org/10.1007/s00784-018-2793-3}

Figure 1 was reused with permission from "Wiley", the publisher of a previous article by the same authors, DOI:10.1111/cid.12518.

Publisher's note Springer Nature remains neutral with regard to jurisdictional claims in published maps and institutional affiliations.

The online version of the original article can be found at https://oi.org/ 10.1007/s00784-018-2793-3

Roni Kolerman

daniaron@netvision.net.il; kolerman@netvision.net.il

1 Department of Periodontology, the Maurice and Gabriela Goldschleger School of Dental Medicine, The Sackler Faculty of Medicine, Tel-Aviv University, Tel-Aviv, Israel

2 Department of Oral Rehabilitation, the Maurice and Gabriela Goldschleger School of Dental Medicine, the Sackler Faculty of Medicine, Tel-Aviv University, Tel-Aviv, Israel

3 Department of General and Implant Dentistry, Faculty of Medicine and Dentistry, University of Murcia, Murcia, Spain 